\title{
Developing an Instrument to Assess Information Technology Staff Motivation
}

\author{
Fernando Belfo ${ }^{1}$ and Rui Dinis Sousa ${ }^{2}$ \\ ${ }^{1}$ Polytechnic Institute of Coimbra, \\ Quinta Agrícola, Bencanta, 3040-316 Coimbra, Portugal, fpbelfo@gmail.com \\ ${ }^{2}$ Algoritmi Research Centre, Information Systems Department, University of Minho \\ Campus de Azurém, 4800-058 Guimarães, Portugal, rds@dsi.uminho.pt
}

\begin{abstract}
Motivation is a key factor that influences individual effort, which, in turn, affects individual and organizational performance. Nevertheless, motivation at work depends on the organizational rewards and incentives, according to individual goals. This paper reports on the development of an instrument designed to measure the motivation of Information Technology people at their workplace. Psychology theories and work addressing intrinsic and extrinsic motivation have been studied. Some motivation instruments were reviewed and analyzed. Specificities and special characteristics regarding IT workers were evidenced and combined with other more general motivation factors. The instrument has been developed according to the five dimensions of the Worldatwork framework, resulting in a set of 30 scale items addressing 23 variables. Besides measuring the IT motivation levels, the tool may also help any organization to understand the weaknesses and strengths regarding incentive policies, and therefore, assist on the definition of new ones.
\end{abstract}

Keywords: motivation, IT management, IT human resources, incentive policy, reward, instrument

\section{Introduction}

Motivation is related with activation and intention. It concerns energy, direction, persistence and equifinality. Its importance in the real world is based on its tangible consequences. Ryan and Deci clearly underlined that importance when they said that "Motivation produces" [1]. Motivation is a central concern of the society - to know how to move ourselves or others to act. "Parents, teachers, coaches, and managers struggle with how to motivate those that they mentor, and individuals struggle to find energy, mobilize effort and persist at the tasks of life and work" [2].

Driving human behavior may vary. People can be oriented to engage in work primarily for its own sake, because the work itself is interesting, engaging, or in some way satisfying. If so, it is usually called intrinsic motivation. It may also be associated to motivation to work primarily in response to something apart from the work itself, such as reward or recognition or to the dictates of other people. This is usually called extrinsic motivation [3]. Ryan and Deci presented definitions about intrinsic and 
extrinsic motivations and some new directions [4]. Among other approaches, these authors contributed with the Self-Determination Theory (SDT), distinguishing between different types of motivation based on the different reasons or goals that give rise to an action. They argued that the most basic distinction between them is that intrinsic motivation refers to doing something because it is inherently interesting or enjoyable, and extrinsic motivation refers to doing something because it leads to a separable outcome. Their review supported that experience quality and performance can be very diverse when one is behaving for intrinsic versus extrinsic reasons $[1,5]$.

WorldatWork, an association representing professions comprising total rewards, proposed an exhaustive reward model composed by five dimensions which are Compensation, Benefits, Work-Life, Performance and Recognition, Development and Career Opportunities [6]. Although it is not an assessment instrument, this model helps to extensively structure motivational dimensions. According to WorldatWork, compensation is a payment provided by an employer to an employee for services rendered (i.e., time, effort and skill) and comprises fixed payment, variable payment, short-term incentive payment and long-term incentive payment. Benefits are programs used to complement the cash payment, usually designed to protect the employee and his or her family from financial risks and can be classified into social insurance, group insurance and payment for time not worked. Another proposed dimension is the Work-life. It consists in a particular group of organizational practices, policies, programs, combined with a attitude which actively supports efforts to assist employees reach success either at work or at home, like workplace flexibility, paid and unpaid time off, health and well-being, caring for dependents, financial support, community involvement or management involvement/culture change interventions. Performance and Recognition, the fourth dimension, promotes the alignment of the organizational, by team and individual performance assessment in order to understand what was accomplished, and how it was accomplished. Performance and Recognition is composed by performance planning, linking individual, team and organizational goals, performance, showing a skill or a capacity and performance feedback, communicating how well worker play a job compared to expectations and recognition that acknowledges or underlines employee actions, efforts, behavior or performance. Finally, Development and Career Opportunities dimension is composed by a set of learning experiences planned to improve employees' practical skills and competencies and an employee plan to pursue career goals and evolve into higher responsible positions in the organization. It also includes Learning Opportunities, Coaching/Mentoring or Advancement Opportunities [7]. According to WorldatWork [6], Total Rewards is "the monetary and non-monetary return provided to employees in exchange for their time, talents, efforts and results".

In the following section of this paper, we perform an analysis of several of the most important motivation assessment instruments. Then, in the third section, we analyze IT staff motivational specificities. Having studied the existing instruments and IT staff motivational specificities, the fourth section presents the instrument we have developed using the WorldatWork model as a cognitive reference. The fifth and last section presents the conclusions pointing out future work. 


\section{Motivation Assessment Instruments}

To define an instrument for assessing the maturity of IT staff motivation, we followed the following steps: (a) analysis of motivation assessment instruments; (b) consideration of IT staff motivational specificities; (c) instrument development. An extensive literature review allowed the identification of a relevant set of motivation assessment instruments: General Causality Orientations Scale, Work Preference Inventory, Harter's instrument, Academic Motivation Scale, Human Resources Survey, Work-Life Questionnaire and Intrinsic Motivation Inventory.

\subsection{General Causality Orientations Scale}

The General Causality Orientations Scale (GCOS) was initially proposed by Deci and Ryan [8]. The strength of three different motivational orientations within an individual are assessed with this scale. These different directions, labeled Autonomy, Controlled, and Impersonal, are understood as relatively enduring facets of personality, and each one is theorized to exist within each individual to some degree. Main scale is composed by three subscales, and a person gets a score on each subscale. The Autonomy Orientation subscale measures the degree to which a person is oriented toward aspects of the environment that stimulate intrinsic motivation. When strong autonomy oriented, people seek opportunities for self-determination and choice. They tend to select jobs that allow greater initiative, have more autonomy and are likely to "organize their actions on the basis of personal goals and interests rather than controls and constraints". The Controlled Orientation subscale measures the degree to which a person is oriented toward being controlled by rewards, deadlines, structures, ego-involvements, and the directives of others. A high controlled orientated person is expected to be dependent on rewards or other controls. These people may be more familiar to what others demand than to what they want for themselves. The Impersonal Orientation subscale measures the degree to which a person believes that attaining desired outcomes is beyond his or her control and that success is mostly a matter of luck. People highly impersonal oriented are likely to be anxious and to "see themselves as incompetent and unable to master situations". They often feel they are not able to affect outcomes or cope with demands or changes [8].

\subsection{Work Preference Inventory}

Work Preference Inventory (WPI) is a specific instrument developed for adults' motivation assessment. It was designed as a direct, explicit assessment of individual differences in the degree to which adults perceive themselves to be intrinsically and extrinsically motivated toward what they do [3]. One underlying assumption was that intrinsic and extrinsic motives might coexist. Like GCOS [8], WPI was set out for scales to be scored independently. The items considered at WPI wanted to capture major elements of both intrinsic and extrinsic motivation. The intrinsic motivation elements include (a) self-determination (preference for choice/autonomy), (b) competence (mastery orientation and preference for challenge), (c) task involvement 
(task absorption and flow), (d) curiosity (preference for complexity) and (e) interest (enjoy and fun). The elements for extrinsic motivation include (a) evaluation, (b) recognition concerns, (c) competition concerns, (d) a focus on money or other tangible incentives, and (e) a focus on the dictates of others.

\subsection{Harter's instrument}

Harter developed an instrument to assess elementary school children's general levels of intrinsic versus extrinsic motivation [9]. This instrument was composed of five subscales: (a) Preference for Challenge vs. Preference for Easy Work, (b) Curiosity/Interest vs. Pleasing the Teacher/Getting Good Grades, (c) Independent Mastery vs. Dependence on the Teacher, (d) Independent Judgment vs. Reliance on the Teacher's Judgment, and (e) Internal Criteria for Evaluation vs. External Criteria for Evaluation. It was assumed that intrinsically motivated students would be more likely to look out for challenging and interesting activities and assignments and would prefer to plan and face difficulties. On the contrary, extrinsically motivated children would prefer easy work more likely to be successful at, and for which they could get credit from the teacher. Also, they would prefer to be assigned with work that they could seek out help from the teacher if difficulties arise [9-10]. Harter's research results showed that both intrinsic and extrinsic motivational orientations are perfectly negatively correlated. In addition, intrinsic motivational orientation systematically decreases with the increasing of age or grade level.

\subsection{Academic Motivation Scale}

Another instrument developed to measure motivation was the Academic Motivation Scale (AMS), originally known as "Echelle de Motivation en Education" (EME) [1112]. This instrument wanted to assess not only the intrinsic and the extrinsic motivation among students, but also amotivation in education. According to Deci and Ryan, there is a third type of motivational construct that should be considered in order to fully understand human behavior [5]. Reporting to a "why" question like "Why do you go to college?", possible items answers reflect different types of motivation. Some items of this AMS scale are: amotivational subscale, "Honestly I don't know; I really feel I wasting my time in the college"; external regulation, "In order to get a more prestigious job latter on", Introjected regulation, "To prove to myself that I can do better than just a high-school degree"; identification regulation, "because eventually it will allow me to enter the job market in a field that I like"; Intrinsic Motivational (IM)- to know, "Because I experience pleasure and satisfaction while learning new things"; IM-Accomplishment, "for the pleasure I experience while surpassing myself in my studies"; IM-stimulation, "for the high feeling that I experience while reading on various interesting subjects". 


\subsection{HR Survey, Work-Life Questionnaire and Intrinsic Motivation Inventory}

An interesting embracing employee's attitude assessment is the Employee Attitude Survey (EAS). Developed by Human Resources Survey (HR Survey), a web based Application Service Provider, EAS wants to offer a picture of organization's needs, providing an understanding of how the employee perceives the organization and work groups. It contains a series of multiple choice items grouped along one or more dimensions of the organization such as creativity, innovation, satisfaction, senior management, interpersonal relations, compensation, mentoring, teamwork and staff development, among others. Its feedback may provide management with employee feedback (both positive and negative) on the internal health of the organization or can be used to motivate employees and improve job satisfaction [13]. Along the same lines, another instrument was studied: the 'University of Pennsylvania Work-Life Questionnaire' (UPWLQ). This questionnaire was designed to provide initial evidence of the usefulness of the Job-Career-Calling distinctions [14]. Finally, it was also analyzed the Intrinsic Motivation Inventory (IMI), a multidimensional measurement device intended to assess participants' subjective experience related to a target activity in laboratory experiments. This instrument assesses six subscale motivation aspects; participants' interest/enjoyment, perceived competence, effort, value/usefulness, felt pressure and tension, and perceived choice while performing a given activity [15].

\section{IT Staff Motivational Specificities}

Motivation specificities among certain specific practitioners' areas have already been object of study. For instance, health practitioners' incentives performance and motivation studies found that the response of physicians to economic incentives inherent in payment mechanisms seems to pursue the expected theory directions. Yet, there is lacking evidence of the effects of incentives on motivation and performance of other health workers [16]. Sport is another specific case. The work developed by Pelletier et al. wanted to measure the motivation toward sport [17]. The reasons why people practice their sports are explored, organized at seven subscales that measure different types of intrinsic motivation, extrinsic motivation and amotivation.

Job satisfaction among IT staff and some of its components (work, supervision, coworkers, pay and promotion), were studied by Igbaria and Guimaraes. Their study showed that role ambiguity was the most dysfunctional variable for IT employees in relation to job satisfaction. Also, the connection between role ambiguity and some components of job satisfaction were found to be education and age dependent. It was also confirmed the significance of job satisfaction in predicting organizational dedication and intentions to go away [18]. Based on Igbaria and Baroudi instrument to measure career incentives, Hsu, Jiang, Klein and Tang constructed a framework of various job anchors to study how a sample of IS staff consider incentives provided by employers and the importance of these in assessing the employee's intent to leave.

Moreover, motivational behavior seems to depend on each kind of work. Igbaria and other authors also investigated the role of involvement in influencing the quality 
of work life. They found significant differences in the level of job involvement by IT employees. The discrepancy strength of job involvement suggests that job characteristics play a major responsibility in IS employees' career expectations and quality of work life [19]. According to Amabile et al.; "perhaps stereotypes of the extrinsically oriented businessperson and the intrinsically oriented scientist or "starving artist" have some kernel of psychological truth" [3]. Daniel Pink defends that the majority of IT professionals use "left brain" skills, while tomorrow's job will require "right brain" skills. This job transformation, transitioning from the old skills to the new skills requires IT practitioners to move from technological skills to artistic skills. Furthermore, organizations should support and reward the new skills, in order to be prepared for the future [20]. Michael Lyons personalities' survey of above 1000 IT professionals working at over 100 international companies evidenced twice as many introverts as extraverts, slightly more intuitive than sensing people, a very high percentage $(80-90 \%)$ of thinking to feeling persons and a $2-1$ ratio of judging to perceiving types. Although thinking IT group is typically much more numerous than feeling ones, as systems tend to move towards integration of a variety of communication facilities, such significant supremacy can slowly be changing [21]. Cloud computing or SOA (Service Oriented Architecture) usage contributes to the advantage of having increasingly artistically minded feelers.

The particular knowledge about what IT professionals look for in their working environments was the objective of the 2004 Information Week Compensation Survey. This survey showed some specificities among IT staff, evidencing some differences between general IT staff and IT managers: (a) more than 55\% of the IT staff and more than $65 \%$ of IT managers believe that their job and responsibilities are not challenging; (b) about $41 \%$ of the IT staff consider that they are not fairly compensated, $12 \%$ of the respondents believe that they got fewer bonuses in 2004 than they got in 2003 and $63 \%$ of the respondents said that higher compensation is the prime reason that they are interested in changing jobs; (c) $50 \%$ of IT staff and $40 \%$ of IT managers appreciate flexible work schedules; more than $40 \%$ are dissatisfied with their company's management or culture; nearly $50 \%$ of IT professionals think they do not have job security; $88 \%$ declare their jobs are stressful [22].

A systematic literature review about specificities among software engineers was recently made by Beecham, Baddoo and Robinson. Despite there are other important IT jobs and that software engineers activity specification is not consensual, this job is still one of the most popular at the IT universe. According to these authors, results indicate that software engineers are likely to be motivated according to their 'characteristics' (e.g., their need for variety); internal 'controls' (e.g., their personality) and external 'moderators' (e.g., their career stage) [23]. Nevertheless, this review stresses that motivation models in Software Engineering are disparate and do not reproduce the complex needs of software engineers. The software engineers' motivation question was analyzed at 62 papers which allowed the creation of a list of 22 different motivators. The most frequently cited motivators are, 'the need to identify with the task' and so, having clear goals defined, "a personal interest", "understanding the purpose of a task", understanding its fitness with the whole, having "job satisfaction"; and "working on an identifiable piece of quality work". Some of these papers also stress the importance of having a "clear career path", having a "variety of tasks", "involving the engineer in decision making" and to 
"participate and work with others" [23]. Supported at this systematic literature review, a new motivation model with detailed factors in software engineering was proposed, classifying factors as extrinsic or intrinsic motivators, some of these inherent at software engineering. Beyond the other intrinsic factors, the identified inherent motivators are: challenging, changing, problem-solving, beneficial, lifecycle models, scientific, experimental, team working, and development practices [24].

Even there were some essays about motivators for IT staff, there is still no specific instrument to measure general and particular IT staff motivation. The instrument proposed in this work will consider typical human motivators and specific IT ones.

\section{Instrument Development}

From the instruments introduced in the previous sections, over 200 items have been analyzed regarding the potential contribution for the instrument. Taking the five dimensions from the reward model [6] to structure variables regarding either general or IT specific motivators, Table 1 and Table 2 present the resulting instrument comprising 30 items across 23 variables. Some of the 30 items come directly from one of the analyzed instruments, others have been adapted and some are new.

Table 1. Variables and scale items for compensation, benefits and perf./recognition dimensions

\begin{tabular}{|c|c|c|c|}
\hline 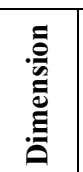 & Variable & Scale Items & 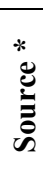 \\
\hline \multirow{4}{*}{ 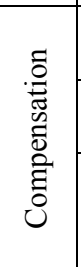 } & Base Wages & $\begin{array}{l}\text { I receive fair base wage for my job compared to others doing } \\
\text { similar work at other companies }\end{array}$ & 2 \\
\hline & Premium Pay & $\begin{array}{l}\text { My company offers a generous premium increases in payment } \\
\text { for on-call work or valued special skills }\end{array}$ & 2 \\
\hline & \multirow[t]{2}{*}{ Variable Pay } & $\begin{array}{l}\text { I am pleased because I'm earning more for what I do if I } \\
\text { largely exceed the objectives }\end{array}$ & 4 \\
\hline & & I understand how my variable payment is determined & 2 \\
\hline \multirow{4}{*}{ 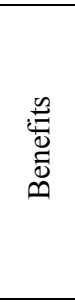 } & $\begin{array}{l}\text { Legally } \\
\text { Required }\end{array}$ & $\begin{array}{l}\text { I feel my company do not meet legal obligation benefits to } \\
\text { each employee (R) }\end{array}$ & 2 \\
\hline & \begin{tabular}{|l|} 
Health \& \\
Welfare \\
\end{tabular} & $\begin{array}{l}\text { My company's offers medical plans or other health or welfare } \\
\text { benefits that meet my needs }\end{array}$ & 2 \\
\hline & Retirement & $\begin{array}{l}\text { I feel the retirement benefits offered by my company meet } \\
\text { employees needs }\end{array}$ & 2 \\
\hline & $\begin{array}{l}\text { Pay for Time } \\
\text { Not Worked }\end{array}$ & $\begin{array}{l}\text { To me, it is very important the company payment for time not } \\
\text { worked, like when I get sick or by other weighty reasons }\end{array}$ & 8 \\
\hline \multirow{5}{*}{ 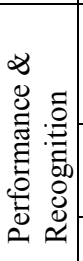 } & \multirow[b]{2}{*}{ Performance } & I understand the measures used to evaluate my objectives & 1 \\
\hline & & $\begin{array}{l}\text { I regularly participate in the company's decision making and } \\
\text { on the performance management system }\end{array}$ & 2 \\
\hline & \multirow{2}{*}{$\begin{array}{l}\text { Job } \\
\text { Assignment }\end{array}$} & I enjoy doing my activity very much. & 6 \\
\hline & & My skills are effectively used on the job & 1 \\
\hline & Recognition & At my company, I am recognized for my accomplishments & 1 \\
\hline
\end{tabular}


Table 2. Variables and scale items for work-life, develop. and career opportunities dimensions

\begin{tabular}{|c|c|c|c|}
\hline$\frac{\overline{0}}{\mathscr{a}}$ & Variable & Scale Items & $\stackrel{*}{*}$ \\
\hline \multirow{13}{*}{ 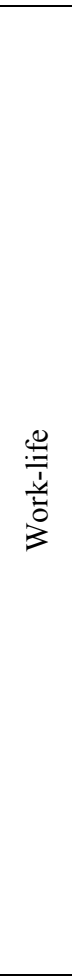 } & \multirow{2}{*}{$\begin{array}{l}\text { Workplace } \\
\text { Flexibility / } \\
\text { Altern. Work } \\
\text { Arrangements }\end{array}$} & $\begin{array}{l}\text { My current position permits me to experience the chance to do } \\
\text { things my own way and not to be constrained by the rules of } \\
\text { an organization }\end{array}$ & 5 \\
\hline & & $\begin{array}{l}\text { I can arrange my work schedule to meet my personal and/or } \\
\text { family needs }\end{array}$ & 1 \\
\hline & $\begin{array}{l}\text { Paid \& Unpaid } \\
\text { Time Off }\end{array}$ & $\begin{array}{l}\text { It is difficult for me to get time off because of } \\
\text { maternity/paternity or sabbatical reasons (R) }\end{array}$ & 8 \\
\hline & $\begin{array}{l}\text { Health and } \\
\text { Wellness }\end{array}$ & $\begin{array}{l}\text { It is important for me to have health or wellness initiatives and } \\
\text { services, like on-site fitness facilities, that are offered by my } \\
\text { company }\end{array}$ & 8 \\
\hline & \multirow{2}{*}{$\begin{array}{l}\text { Community } \\
\text { Involvement }\end{array}$} & $\begin{array}{l}\text { I am proud to be working at my company because my work } \\
\text { and my company makes the world a better place }\end{array}$ & 7 \\
\hline & & $\begin{array}{l}\text { My current position permits me to experience a career in } \\
\text { which I can be committed and devoted to an important cause }\end{array}$ & 5 \\
\hline & \begin{tabular}{|l|} 
Caring for \\
Dependents
\end{tabular} & $\begin{array}{l}\text { My company helps employees caring for their child and } \\
\text { dependents }\end{array}$ & 8 \\
\hline & \begin{tabular}{|l|} 
Financial \\
Support \\
\end{tabular} & $\begin{array}{l}\text { My company offers financial support to meet my family } \\
\text { needs, like education ones }\end{array}$ & 8 \\
\hline & \begin{tabular}{|l|} 
Voluntary \\
Benefits
\end{tabular} & $\begin{array}{l}\text { I don't give so much importance to benefits offered like } \\
\text { parking, employee discounts or car/home insurance (R) }\end{array}$ & 8 \\
\hline & \multirow{2}{*}{$\begin{array}{l}\text { Cultural } \\
\text { Environment }\end{array}$} & My company values team work and diversity & 2 \\
\hline & & Senior managers listen to me and care about my ideas & 1 \\
\hline & $\begin{array}{l}\text { Workplace } \\
\text { Stability }\end{array}$ & $\begin{array}{l}\text { My current position permits me to experience remaining in my } \\
\text { area of expertise throughout my career }\end{array}$ & 5 \\
\hline & \begin{tabular}{|l|} 
Available \\
Equip. \& Data
\end{tabular} & $\begin{array}{l}\text { My company provides me with the necessary data and } \\
\text { technological resources to do my job well }\end{array}$ & 2 \\
\hline \multirow{4}{*}{ 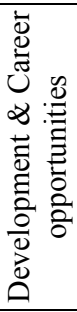 } & \begin{tabular}{|l|l} 
Learning \\
Opportunities
\end{tabular} & $\begin{array}{l}\text { My work allow me with opportunities for increasing my } \\
\text { knowledge and skills. }\end{array}$ & 4 \\
\hline & $\begin{array}{l}\text { Coaching / } \\
\text { Mentoring }\end{array}$ & My supervisor is an effective role models for me & 1 \\
\hline & \multirow{2}{*}{$\begin{array}{l}\text { Advancement } \\
\text { Opportunities }\end{array}$} & $\begin{array}{l}\text { My current position permits me to develop a career that } \\
\text { permits to continue to pursue my own lifestyle }\end{array}$ & 5 \\
\hline & & $\begin{array}{l}\text { My current position permits me to success by being constantly } \\
\text { challenged by a tough problem or a competitive situation }\end{array}$ & 5 \\
\hline
\end{tabular}

Carefully observed when developing, adapting or using an existing item was the guarantee that a particular assessment of personal motivation was asked according to what was offered by the respondents' particular company and not about general intrinsic or extrinsic motivation out of organizational context. This was particular 
important for the adaptation of items from WPI and not so with items coming from IMI or HRSurvey. Moreover, each item assesses one Worldatwork dimension and sub-dimension (variable). As there are 23 sub-dimensions (grouped in 5 dimensions), there are one or two items for each variable. Furthermore, this instrument scores each answer on a 5-point Likert-type scale anchored by the extreme points " 1 = strongly disagree" to " $5=$ strongly agree". It also does allow a middle placement. Although the middle point is sometimes selected by responders who are either indecisive or not concerned, which can cause bias in the measurement of satisfaction levels, it also can be applied to questions requiring a middle position, such as when respondent has no strong opinion one way or the other. So, it was decided to have a middle point " $3=$ neither agree nor disagree". Three of the questions were reverse coded. This is a procedure where a few number of questions in the questionnaire are worded such that high values for the construct are valued by low scores on the item. The objective in implementing this procedure is to force respondents to really pay attention to the questions they are answering.

\section{Conclusions}

This work was just a first step for the development of an instrument to assess IT staff motivation. We started with existing motivational instruments having reviewed over 200 items in the light of the WorldatWork reward model. Taking into consideration IT staff motivation specificities, we added a few variables to the reward model. Then, either adopting or adapting existing or developing new items, we have come up with a first representative set of 30 items for the variables that comprise now the five dimensions of our reward model for IT staff. Future work should look into the content validity of the proposed instrument by pre-testing it in IT settings. To ensure later the construct validity of IT staff motivation, we are planning to use the developed instrument in the context of business-IT alignment research. Organizations that have motivated IT employees should be particularly better positioned to pursue and keep business-IT alignment.

\section{References}

1. Ryan, R., Deci, E.: Self-determination theory and the facilitation of intrinsic motivation, social development, and well-being. American psychologist. 1, pp. 68-78 (2000)

2. Deci, E., Ryan, R., Self-Determination Theory, http://www.psych.rochester.edu/SDT/

3. Amabile, T., Hill, K., Hennessey, B., Tighe, E.: The work preference inventory: Assessing intrinsic and extrinsic motivational orientations. Journal of Personality and Social Psychology. S3, pp. 00 (1994)

4. Ryan, R., Deci, E.: Intrinsic and Extrinsic Motivations: Classic Definitions and New Directions* 1. Contemporary educational psychology. 1, pp. 54-67 (2000)

5. Deci, E., Ryan, R.: Intrinsic motivation and self-determination in human behavior: Springer (1985)

6. WorldatWork, T.T.R.A., Total Rewards Model, WorldatWork Association. (2008) 
7. Belfo, F.: Influence of incentive policy in strategic alignment of information technology and business. In: Proceedings of the CENTERIS'2010 - Conference on ENTERprise Information Systems - aligning technology, organizations and people. Communications in Computer and Information Science. Viana do Castelo, Portugal: Springler. (2010)

8. Deci, E.L., Ryan, R.M.: The general causality orientations scale: Self-determination in personality* 1. Journal of research in personality. 2, pp. 109-134 (1985)

9. Harter, S.: A new self-report scale of intrinsic versus extrinsic orientation in the classroom: Motivational and informational components. Developmental Psychology. 3, pp. 300-312 (1981)

10.Lepper, M., Sethi, S., Dialdin, D., Drake, M.: Intrinsic and extrinsic motivation: A developmental perspective. Developmental psychopathology: Perspectives on adjustment, risk, and disorder. pp. 23-50 (1997)

11. Vallerand, R., Pelletier, L., Blais, M., Briere, N., Senecal, C., Vallieres, E.: On the assessment of intrinsic, extrinsic, and amotivation in education: Evidence on the concurrent and construct validity of the Academic Motivation Scale. Educational and Psychological Measurement. 1, pp. 159 (1993)

12. Vallerand, R.J., Pelletier, L.G., Blais, M.R., Briere, N.M., Senecal, C., Vallieres, E.F.: The Academic Motivation Scale: A measure of intrinsic, extrinsic, and amotivation in education. Educational and Psychological Measurement. 4, pp. 1003 (1992)

13.HR-Survey, L., Employee Attitude Survey, http://www.hr-survey.com/

14. Wrzesniewski, A., McCauley, C., Rozin, P., Schwartz, B.: Jobs, careers, and callings: People's relations to their work. Journal of research in personality. pp. 21-33 (1997)

15. McAuley, E.: Psychometric Properties of the Intrinsic Motivation Inventory in a Competitive Sport Setting: A Confirmatory Factor Analysis. Research Quarterly for Exercise and Sport. 1, pp. 48-58 (1989)

16. Adams, O., Hicks, V.: Pay and non-pay incentives, performance and motivation. (2000)

17.Pelletier, L.G., Blais, M.R.: Toward a new measure of intrinsic motivation, extrinsic motivation, and amotivation in sports: The Sport Motivation Scale (SMS). Journal of Sport and Exercise Psychology. pp. 35-35 (1995)

18.Igbaria, M., Guimaraes, T.: Antecedents and consequences of job satifaction among information center employees. Proceedings of the 1992 ACM SIGCPR Conference on Computer Personnel Research. 2, (1992)

19.Igbaria, M., Parasuraman, S., Badawy, M.K.: Work experiences, job involvement, and quality of work life among information systems personnel. MIS quarterly. pp. 175-201 (1994)

20.Pink, D.: A whole new mind: Riverhead Books (2005)

21.Kaluzniacky, E.: Increasing the Effectiveness of IT Management through Psychological Awareness, In Managing IT professionals in the Internet age, P. Yoong and S.L. Huff, Editors. Idea Group Publishing. p. 191-232. (2006)

22.Luftman, J., Kempaiah, R.: IT Professionals: Human Resource, In Managing IT professionals in the Internet age, P. Yoong and S.L. Huff, Editors. Idea Group Publishing. p. 159-190. (2006)

23.Beecham, S., Baddoo, N., Hall, T., Robinson, H., Sharp, H.: Motivation in Software Engineering: A systematic literature review. Information and Software Technology. 9-10, pp. 860-878 (2008)

24. Sharp, H., Baddoo, N., Beecham, S., Hall, T., Robinson, H.: Models of motivation in software engineering. Information and Software Technology. 1, pp. 219-233 (2009) 